\title{
KEBANGKRUTAN LEMBAGA PERKREDITAN DESA (LPD) BERDASARKAN ANALISIS BERBAGAI FAKTOR
}

\author{
Komang Adi Kurniawan Saputraa,*, A.A. Ayu Erna Trisnadewib, \\ Putu Budi Anggiriawanc, Putu Gede Wisnu Permana Kawisana ${ }^{\mathrm{d}}$ \\ a,b,c,d Universitas Warmadewa, Jalan Terompong No. 24, Denpasar, Bali \\ Indonesia \\ *(adikurniawan@warmadewa.ac.id)
}

\begin{abstract}
ABSTRAK
Penelitian ini bertujuan untuk menginvestigasi beberapa faktor yang memengaruhi kebangkrutan LPD di Kabupaten Buleleng - Bali, yaitu faktor perlindungan hukum, kompetensi manajerial, good corporate governance, peran aktif dari warga negara dan peran badan-badan pengawas internal. Metode dalam kajian ini menggunakan kuesioner dengan 63 responden yaitu manajer LPD dan untuk analisis data menggunakan analisis regresi berganda. Hasil studi ini menunjukkan bahwa hanya kompetensi manajerial dan peran badanbadan pengawas internal yang memiliki pengaruh pada potensi kebangkrutan LPD, sementara variabel perlindungan hukum, good corporate governance dan peran serta warga tidak mempengaruhi potensi kebangkrutan LPD di Kabupaten Buleleng - Bali.
\end{abstract}

Kata kunci: perlindungan hukum, good corporate governance, peran badanbadan pengawas internal, kebangkrutan

\section{ABSTRACT}

This study aims to examine several factors that influence the bankruptcy of LPDs in Buleleng Regency of Bali Province, i.e. legal protection, managerial competence, good corporate governance, the active role of citizens and the role of internal supervisory bodies. In this study using a questionnaire method with 63 respondents namely LPD managers and for data analysis use multiple regression analysis. The results of this study state that only the manager's competence and the role of internal supervisory bodies have an influence on the potential of LPD bankruptcy, while legal protection variables, good corporate governance and the active role of citizens do not affect the potential for bankruptcy LPD in Buleleng Regency of Bali Province.

Keywords: legal protection, good corporate governance, internal supervisory bodies, bankruptcy 


\section{PENDAHULUAN}

LPD memiliki peran yang sangat penting dalam meningkatkan perekonomian dan kesejahteraan krama desa pakraman. Dengan adanya LPD, krama desa pakraman tidak lagi mengalami kesulitan dalam memperoleh dana bagi kegiatan konsumtif maupun produktifnya. Bahkan, yang tidak kalah mengagumkannya adalah berbagai kontribusi LPD kepada desa pakraman dalam bentuk pemberian bantuan dana ritual, dana pembangunan, beasiswa bagi krama yang tidak mampu maupun aktivitasaktivitas filantropis lainnya (Warren, 2010; Sulistiyowati, 2011).

Meskipun secara umum LPD dapat dikatakan berhasil secara menakjubkan sehingga dipuji oleh berbagai pihak, namun tidak dapat dipungkiri bahwa terdapat pula LPD yang berada dalam kondisi bermasalah, bahkan mengalami kebangkrutan (Saputra, 2015). Dari data yang mengemuka dalam rapat koordinasi yang membahas tentang LPD antara Komisi II DPRD Bali, Bank Pembangunan Daerah Bali, Pemda Propinsi Bali, Majelis Utama Desa Pakraman dan sejumlah akademisi di Denpasar tanggal 12 Nopember 2010, terdapat 173 LPD dari total 1.405 LPD yang ada di Bali yang mengalami kebangkrutan.
Meskipun jumlah LPD yang bangkrut cukup besar hingga mencapai lebih dari $12 \%$ dari keseluruhan LPD, namun keberadaanya kurang memperoleh perhatian (Atmadja, dkk, 2015).

Jumlah Lembaga Perkreditan Desa (LPD) di Kabupaten Buleleng sebanyak 169 LPD. Dari jumlah itu diklasifikasikan dalam beberapa kategori: LPD sehat sebanyak 106 unit; LPD cukup sehat 11 unit; LPD kurang sehat 14 unit; LPD tidak sehat 3 unit; LPD macet 27 unit; LPD tidak lapor 5 unit; dan LPD baru operasional 3 unit. Dari kondisi ini beberapa LPD mengalami permasalahan-permasalahan yang mengakibatkan dampak kurang baik terhadap LPD -LPD yang bagus, bahkan ada beberapa LPD yang sudah masuk ke ranah hukum. Dalam hal ini Kelian Desa Pakraman selaku ketua badan pengawas internal internal dituntut peranannya melaksanakan fungsi-fungsi pengawasan sehingga dapat meminimalis penyelewenganpenyelewengan keuangan (Saputra dan Kurniawan, 2017).

Berdasarkan latar belakang masalah diatas, dapat diidentifikasi faktor-faktor yang dominan dialami oleh LPD, diantaranya adalah: 1) Lembaga Perkreditan Desa sebagai lembaga non-bank hanya diproteksi 
dengan awig-awig untuk mengatur tentang tata kelola LPD sebagai milik desa pakraman. Berpijak pada Perda/Pergub tentang LPD sebagai lembaga keuangan berbasis adat perlu diperkuat dan ditegaskan terkait hal-hal yang memberikan keleluasaan ruang lingkup LPD. Artinya, dibutuhkan aturan yang detail, termasuk didalamnya adalah tentang sanksi pidana dan diperlukan semacam Lembaga Penjamin Simpanan (LPS) yang khusus untuk LPD, karena LPD tidak sama dengan perbankan atau lembaga keuangan mikro sehingga tidak masuk dalam LPS. 2) SDM yang dimiliki LPD sekarang ini masih minim pengetahuan tentang aturan dan perlu ditingkatkan kualitasnya, sehingga dapat dikatakan bahwa pengurus LPD perlu meningkatkan kompetensinya mulai dari pengelolaan hingga pengawasan.3) Perlu memberlakukan prinsip good corporate governance dalam LPD. 4) Peran aktif warga desa pakraman dalam pengembangan LPD. 5) Perlunya pengoptimalan peran badan pengawas internal desa yang sudah ada.

Dari uraian yang telah dikemukakan diatas, maka rumusan masalah yang dapat diangkat untuk dikaji lebih jauh dan dapat ditindak lanjuti dengan penelitian ini adalah apakah ada pengaruh proteksi hukum, kompetensi pengelola, good corporate governance, peran aktif warga, dan peranbadan pengawas internalterhadap kebangkrutan yang dialami LPD?

\section{TELAAH LITERATUR DAN PERUMUSAN HIPOTESIS}

\section{Lembaga Perkreditan Desa (LPD)}

Lembaga Perkreditan Desa yang selanjutnya disebut dengan LPD adalah merupakan salah satu Lembaga Keuangan Mikro yang ada di Bali adalah. LPD merupakan jenis lembaga keuangan mikro yang memiliki keunikan tersendiri dibandingkan dengan lembaga keuangan mikro lainnya. Kepemilikan LPD iniadalah desa adat di Bali yang secara otomatis merupakan milik masyarakat desa. Posisi LPD ini terletak ditengah-tengah masyarakat desa adat, oleh karena itu maka nasabahnya adalah masyarakat desasetempat baik sebagai debitur maupun kreditur. Dalam mencapai tujuannya, LPD tidak semata menggunakan modal sosial dalam struktur pengendaliannya.Sebagai sebuah lembaga keuangan yang bersifat formal, LPD harus pula menggunakan struktur pengendalian intern.Struktur pengendalian intern ini bertujuan untuk menciptakan keandalan pelaporan keuangan, 
ketaatan terhadap undang-undang dan peraturan yang berlaku serta efektifitas dan efesiensi operasi (Hartadi, 1999).

\section{Desa Pakraman}

Desa pakraman merupakan lembaga tradisional yang dikenal pula dengan nama desa adat. Ada beberapa ciri yang melekat pada sebuah desa pakramandi Bali, yaitu; 1) wilayah dengan batas yang jelas, anggota (krama) dengan persyaratan tertentu, 2) kahyangan tiga atau pura lain yang memiliki peranan yang sama dengan kahyangantiga, 3) otonomi baik ke dalam maupun ke luar, dan 4) pemerintahan adat dengan kepengurusannya (Pitana, 1994). Keseluruh komponen desa pakraman dalam kesehariannya dilandasi oleh tata aturan yang disebut awig-awig. Awig-awig dapat bersifat tertulis dan bisa juga tidak tertulis yang dirumuskan oleh segenap krama desa pakraman melalui paruman krama desa pakraman. Hal inilah yang menjadikan desa pakraman seringkali disebut sebagai sebuah republik kecil (Covarubias, 1972: 58).

Keikutsertaan desa pakraman dalam struktur keorganisasian LPD, yakni bertindak tak ubahnya seperti dewan komisaris, sebagai yang digariskan dalam teks Perda Nomor 8
Tahun 2002, menimbulkan implikasi, pertama, desa pakraman bisa memasukkan modal sosial yang mereka miliki ke dalam asas normatif yang berlaku di LPD. Kedua, desa pakraman bisa ikut melakukan kontrol internal. Ketiga, desa pakraman bisa mengenakan sanksi terhadap pelanggaran yang dilakukan baik oleh manajemen LPD maupun nasabah LPD.Bentuk-bentuk sanksi yang diterapkan berupa digunjingkan, dicemohkan, ditegur, didenda, disepekang, dilarang menggunakan fasilitas desa atau diusir.Dengan adanya sanksi ini diharapkan pihak manajemen maupun nasabah LPD dapat berperan sesuai dengan statusnya sehingga eksistensi LPD tetap terjaga.

\section{Regulasi Tentang LPD}

Pada tahun 1984 dengan Surat Keputusan (SK) Gubernur No. 972 Tahun 1984 tentang Pendirian Lembaga Perkreditan Desa di Provinsi Daerah Tingkat I Bali. proyek pendirian LPD mulai dilakukan dan keberadaan LPD diatur dibawah Peraturan Daerah (PERDA) yakni Peraturan Daerah Provinsi Bali Nomor 8 Tahun 2002 Tentang Lembaga Perkreditan Desa (LPD), yang kini telah diganti menjadi Peraturan Daerah Provinsi Bali Nomor 3 Tahun 2007. Perda tersebut mengatur 
mengenai syarat-syarat pendirian LPD. Pemerintah Provinsi Bali mengeluarkan Peraturan Daerah Provinsi BaliNomor 4 Tahun 2012 TentangPerubahan Kedua Atas Peraturan Daerah Provinsi Bali Nomor 8 Tahun 2002 Tentang Lembaga Perkreditan Desa yang menjadi dasar pelaksanaan LPD saat ini.

Disahkannya Undang-Undang (UU) Nomor 1 tahun 2013 tentang Lembaga Keuangan Mikro memang sudah sepantasnya diapresiasi positif. Dalam UU ini keberadaan LPD (Lembaga Perkreditan Desa) diakui keberadaannya sebagai lembaga keuangan yang bersifat khusus sehingga pengaturannya dikecualikan dari UU tersebut. Hal ini ditegaskan dalam Bab XIII Ketentuan Peralihan pasal 39 ayat 3 yang berbunyi: "Lembaga Perkreditan Desa dan Lumbung Pitih Nagari serta lembaga sejenis yang telah ada sebelum Undang-Undang ini berlaku, dinyatakan diakui keberadaannya berdasarkan hukum adat dan tidak tunduk pada ini”. Pasal 39 ayat 3 dalam UU LKM tersebut menegaskan dua hal penting dalam kaitannya dengan kedudukan LPD: (1) LPD memang bukan LKM sehingga tidak tunduk pada UU LKM, serta (2) LPD merupakan lembaga adat karena diatur berdasarkan hukum adat (awig-awig). Walaupun sudah ada
Perda dan Pergub yang mengatur tentang LPD yaitu Perda Provinsi Bali Nomor 4 Tahun 2012 dan Pergub Nomor 11 tahun 2013 tentang LPD yang telah memuat beberapa hal diantaranya seperti LPD dapat didirikan dengan modal awal sekurang-kurangnya Rp.20 juta. Selain itu pada pasal 26 diatur menyangkut pidana, dimana bagi pengurus atau karyawan yang melakukan kecurangan dan memperkaya diri sendiri akan dikenakan pidana kurungan paling lama 3 bulan atau denda sebanyak Rp.50 juta. Namun, tetap dalam menjalankan LPD agar menempuh prosedur administrasi sesuai aturan secara tegas dan jujur serta terus berkoordinasi dengan Badan pengawas internal. Realisasi pasalpasal yang terkandung dalam aturan ini setidaknya perlu segera dilakukan agar tidak memicu semakin banyaknya kecurangan yang dialami LPD sehingga mengalami kondisi yang kurang menguntungkan atau bangkrut.

\section{Perumusan Hipotesis}

Proteksi hukum merupakan hal yang sangat penting untuk keberlangsungan LPD saat ini, dapat dibuktikan dari banyaknya LPD yang bangkrut pada saat ini diakibatkan karena kecurangan yang dilakukan 
baik oleh pengelola LPD itu sendiri sampai ketidakpatuhan warga masyarakat akan awig-awig desa tersebut. Faktor kejelasan dan ketegasan hukum sangat dibutuhkan saat ini oleh masyarakat dan LPD supaya menghindari judgement negatif dari pihak eksternal LPD. Dengan adanya kepastian hukum di LPD dipandang mampu menjamin kepercayaan masyarakat terhadap operasional LPD ditengah-tengah masyarakat desa. Seperti yang dimuat dalam harian Bali Post tanggal 27 Pebruari 2013 bahwa LPD harus didukung aturan proteksi dana masyarakat, hal itu adalah bagian dari sangat dibutuhkannya proteksi hukum bagi masyarakat.

Berdasarkan kajian diatas, maka dapat dirumuskan hipotesis dari penelitian ini adalah:

$\begin{array}{rlr}\mathrm{H}_{1}: & \text { Proteksi hukum berpengaruh } \\ & \text { signifikan } & \text { terhadap } \\ & \text { kebangkrutan LPD }\end{array}$

Kompetensi pengelola juga bukan hal yang pantas untuk dilupakan oleh semua pihak yang berkepentingan dengan LPD. Hal ini menjadi salah sati faktor penentu baik atau buruknya kinerja LPD, serta mampu atau tidaknya LPD bertahan dalam situasi ekonomi kemasyarakatan yang semakin hari akan semakin kompleks, dengan adanya BPR atau Koperasi.

Seperti yang dimuat pada harian Bali Post tanggal 2 Oktober 2013 bahwa "LPD Tukadaya Bangkrut", hal ini disebabkan karena kecurangan/korupsi yang dilakukan oleh salah satu pengelola LPD disana. Pengelola LPD yang dimaksud adalah kasir yang bertugas dengan mengambil uang sebesar Rp.200 juta. Permasalahan ini sampai menyebabkan LPD tersebut "tidur". Hingga dengan adanya kasus ini, bendesa Tukadaya masih belum mampu mengambil langkah-langkah untuk mengembalikan LPD-nya. Hal inilah yang sering menghantui masyarakat desa untuk percaya sepenuhnya terhadap LPD. Sehingga, hal utama yang perlu dilakukan adalah meningkatkan kompetensi pengelola mulai dari pengelolaan hingga pengawas.

Berdasarkan kajian diatas, maka dapat dirumuskan hipotesis dari penelitian ini adalah:

$\begin{array}{llr}\mathrm{H}_{2}: & \text { Kompetensi } & \text { pengelola } \\ & \text { berpengaruh } & \text { signifikan } \\ & \text { terhadap kebangkrutan LPD }\end{array}$

Good corporate governance perlu diimplementasikan pada LPD yang ada di Bali, khususnya di Kabupaten Buleleng karena prinsip GCG ini dapat memproteksi LPD dari tindak 
kecurangan keuangan yang dilakukan oleh pihak-pihak yang berkepentingan dengan LPD ini. Perilaku oportunistik pengelola/ pimpinan dapat diminimalisasi dengan good corporate governance. Dengan mengurangi peluang bagi manajer/pimpinan pengelola LPD untuk berperilaku menyimpang dan memperkaya diri sendiri diharapkan nilai perusahaan/lembaga akan meningkat, yaitu ditandai dengan meningkatnya aset dari LPD dan meningkatnya nilai tabungan dari masyarakat.

Berdasarkan kajian diatas, maka dapat dirumuskan hipotesis dari penelitian ini adalah:

$\mathrm{H}_{3}:$ Good corporate
berpengaruh
terhadap kebangkrutan LPD

Peran aktif warga menjadi hal yang penting dalam perkembangan LPD. Masyarakat harus aktif menanyakan perkembangan LPD, agar jangan sampai masyarakat cuek dan terkesan tidak perduli akan keberlangsungan dan perkembangan LPD di desanya. Sekarang ini muncul isu dimasyarakat bahwa LPD hanya dinikmati oleh masyarakat yang memiliki kedekatan dengan bendesa adat, tokoh masyarakat atau pimpinan desa yang lainnya. Opini dari masyarakat ini muncul karena kebijakan yang diambil oleh bendesa adat sering menguntungkan beberapa pihak dan tidak mengakomodir aspirasi seluruh masyarakat, hal ini sudah meleset dari LPD yang dimiliki oleh krama desa.

Berdasarkan kajian diatas, maka dapat dirumuskan hipotesis dari penelitian ini adalah:

$\mathrm{H}_{4}$ : Peran aktif warga masyarakat berpengaruh signifikan terhadap kebangkrutan LPD

Peran badan pengawas internal adalah suatu hal yang sering menjadi harapan bagi masyarakat desa untuk kepentingan perkembangan LPD. Harapan tersebut muncul karena peran dari Badan pengawas internal Desa yang selanjutnya disebut dengan Badan pengawas internal dalam pemberian kredit di LPD tidak terlalu terlihat. Selama ini BPD hanya sebagai perpanjangan tangan dari kelian desa, seharusnya badan pengawas internal ini memiliki peran dan lingkup pekerjaaan yang independen dan tanpa intervensi dari siapapun. Sering terjadi di masyarakat bahwa BPD hanya sebagai pelengkap dalam struktur organisasi di desa saja. Seharusnya badan pengawas internal ini bekerja atas nama masyarakat desa, karena badan pengawas internal ini dibentuk dan diberhentikan oleh masyarakat 
dan bukan oleh orang perorang yang berpengaruh di desa seperti kelian desa atau kepala desa.

Berdasarkan kajian diatas, maka dapat dirumuskan hipotesis dari penelitian ini adalah:

$\mathrm{H}_{5}$ : Peran Badan pengawas internal berpengaruh signifikan terhadap kebangkrutan LPD

\section{METODE}

\section{Jenis Penelitian}

Metode yang digunakan dalam penelitian ini adalah empirical study yang berfokus pada metode studi empiris, dimana hipotesis yang diajukan akan menjelaskan fenomena yang ada dalam bentuk hubungan antar variabel. Berdasarkan desainnya, penelitian ini merupakan penelitian survey karena pengambilan sampel dari populasi dan menggunakan kuesioner sebagai data pokoknya.

\section{Jenis dan Sumber Data}

Data yang dipergunakan dalam penelitian ini adalah data primer yang diperoleh langsung dari responden (subyek penelitian) dalam kuesioner penelitian. Data primer yang dikumpulkan meliputi proteksi hukum, kompetensi pengelola, good corporate governance, peran aktif warga, dan peranbadan pengawas internal serta kebangkrutan LPD.

\section{Populasi dan Sampel}

Populasi dari penelitian ini adalah LPD Se-Kabupaten Bulelengyang terdiri dari 9 (sembilan) kecamatan, yaitu kecamatan Tejakula, Kubutambahan, Sawan, Buleleng, Sukasada, Banjar, Busungbiu, Gerokgak dan Seririt, dimana jumlah LPD di Kabupaten Buleleng sampai saat ini adalah berjumlah 169 LPD yang tersebar diseluruh desa/kelurahan. Responden dari penelitian ini adalah pengelola LPD.

Alasan pemilihan sampel ini adalah untuk spesifikasi penelitian yang dilakukan sehingga memudahkan dalam melakukan evaluasi pengelolaan LPD secara parsial, maka penentuan jumlah sampel menggunakan rumus Slovin (Usman, 2007). Dari hasil perhitungan rumus Slovin tersebut didapatkan 63 (enam puluh tiga) sampel LPD yang digunakan dalam penelitian ini.

\section{Metode Pengumpulan Data}

Data primer dalam penelitian ini adalah data yang diperoleh dan dikumpulkan langsung dari lokasi penelitian melalui kuesioner yang diberikan kepada responden, sementara kuesioner yang digunakan bersumber dari kajian terdahulu dan pembuatan kuesioner dengan 
modifikasi melalui teori serta disesuaikan dengan kebutuhan dari objek penelitian dan indikator yang telah teruji validitas dan reliabilitasnya.

\section{Definisi Operasional Variabel}

Variabel Bebas

1. Variabel Proteksi Hukum $\left(\mathrm{X}_{1}\right)$ dengan indikator sebagai berikut:

a) Adanya Sanksi yang tegas

b) Adanya Standar Operasional Prosedur

c) Kepatuhan terhadap aturan otoritas keuangan

d) Adanya lembaga penjamin simpanan

2. Variabel Kompetensi Pengelola $\left(\mathrm{X}_{2}\right)$, dengan indikator sebagai berikut:
a) Latar belakang pendidikan
b) Pengetahuan tentang organisasi
c) Pengalaman kerja

\section{Variabel Good Corporate}

Governance $\left(\mathrm{X}_{3}\right)$, dengan indikator sebagai berikut:
a) Keterbukaan
b) Akuntabilitas
c) Pertanggungjawaban
d) Kewajaran
e) Independensi

4. Variabel Peran aktif warga $\left(\mathrm{X}_{4}\right)$, dengan indikator sebagai berikut:
a) Keterlibatan
dalam pengambilan keputusan
b) Keterlibatan dalam menentukan kebijakan
c) Melaporkan segala bentuk kecurangan
d) Aktif menanyakan perkembangan lembaga

5. Variabel Peran Badan pengawas internal $\left(\mathrm{X}_{5}\right)$, dengan indikator sebagai berikut (Wedayani dan Jati, 2013):
a) Independensi
b) Kemampuan Profesional
c) Lingkup Pekerjaan
d) Pelaksanaan Kegiatan Pemeriksaan

Variabel Terikat

Kebangkrutan LPD, secara konsep hal ini didefinisikan bahwa dimana perusahaan/lembaga tidak mampu menyelesaikan masalah keuangannya. Dalam konsep ini diturunkan indikatornya yaitu:

a) Adanya konflik

b) Kondisi keuangan melemah

c) Jumlah aset berkurang

d) Kontribusi dalam pembangunan desa berkurang

e) Rendahnya tingkat kepercayaan masyarakat

Skala yang digunakan untuk variabel-variabel bebas dan terikat menggunakan skala likert dengan 4 pilihan. Skala likert ini termasuk 
dalam tingkatan skala pengukuran ordinal.

\section{Teknik Pengujian Instrumen}

\section{Uji Validitas}

Alat yang dapat digunakan dalam pengujian validitas suatu kuesioner adalah angka hasil korelasi antara skor pernyataan dan skor keseluruhan pernyataan responden terhadap informasi dalam kuesioner. Jenis korelasi yang digunakan di sini adalah korelasi product momentantara skor setiap pernyataan dengan skor total item dengan tingkat signifikansinya adalah 0,05. Suatu item dikatan valid jika probabilitas koefisien korelasinya lebih kecil dari 0,05 .

\section{Uji Reliabilitas}

Uji realibilitas dilakukan dengan bantuan SPSS (Statistical Product and Service Solution)yang memberikan fasilitas untuk mengukur reliabilitas dengan uji statistik alpha cronbach (a). Suatu variabel dikatakan reliabel jika memenuhi $\mathrm{a} \geq 0,60$ (Nunnally, 2003 dalam Uyanto, 2009).

\section{Uji Asumsi Klasik}

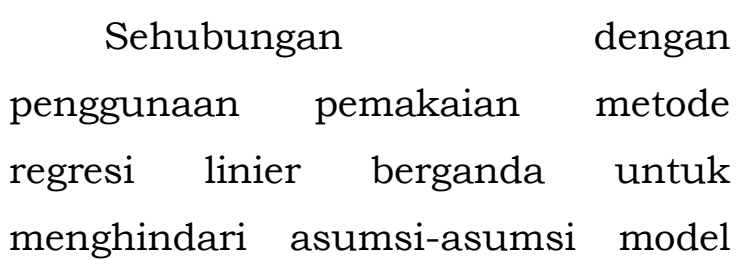

klasik, maka akan dilakukan pengujian sebagai berikut:

1. Uji Multikolinearitas

Uji multikolinearitas bertujuan untuk menguji apakah dalam model regresi terdapat korelasi antarvariabel independen. Model regresi yang baik seharusnya tidak terjadi korelasi di antara variabel bebas. Untuk mendeteksi ada atau tidaknya multikolinearitas adalah sebagai berikut:

a) Nilai $R^{2}$ yang dihasilkan oleh suatu estimasi model empiris sangat tinggi, tetapi secara individual variabel-variabel bebas banyak yang tidak signifikan mempengaruhi variabel dependen.

b) Menganalisa matrik korelasi variabel-variabel bebas. Jika antarvariabel bebas ada korelasi yang cukup tinggi (umumnya 0.90), maka hal ini merupakan indikasi adanya multikolinearitas.

c) Multikolinearitas dapat juga dilihat dari (1) nilai tolerance dan lawannya (2) variance inflation factor (VIF). Batas dari tolerance value adalah 0.10 dan batas dari VIF adalah 10. Jika tolerance value di bawah 0.10 atau nilai VIF di atas 10, maka terjadi multikolinearitas. 
2. Uji Heteroskedastisitas

Model regresi yang baik bersifat homokedastisitas, yaitu residual mempunyai varian yang sama dari satu pengamatan ke pengamatan yang lain. Jika variannya tidak sama, maka dikatakan bersifat heteroskedastisitas.

Heteroskedastisitas

tidak merusak konsistensi estimator tetapi estimator menjadi tidak memiliki varian minimum atau tidak efisien, sehingga pengujian statistik menjadi bias. Salah satu cara untuk mendeteksi adanya heteroskedastisitas adalah menggunakan uji gletser (Uyanto, 2009). Gletser mengusulkan untuk meregresi nilai absolute residual (Ut) terhadap variabel bebas. Jika variabel bebas secara statistik signifikan mempengaruhi variabel terikat (Ut), maka ada indikasi terjadi heteroskedastisitas.

\section{Uji Normalitas}

Uji normalitas bertujuan untuk menguji apakah variabel dependen dan independen dalam model regresi berdistribusi normal atau tidak. Asumsi normalitas dianggap terpenuhi bila data yang digunakan cukup besar $(n>30)$. Untuk menguji normalitas data digunakan analisis grafik dan uji statistik KolmogorovSmirnov Test (Uyanto, 2009).

\section{Metode Analisis Data}

Untuk menganalisis data, yang digunakan adalah metode regresi linear berganda dengan model OLS dengan menggunakan software SPSS for Windows Realesed 17.0 Programe. Metode ini merupakan salah satu cara perhitungan koefisien regresi statistik yang tidak bias, efisiensi dan konsistensi. Metode ini dapat diformulasikan dalam rumus regresi linear berganda sebagai berikut:

$\mathbf{Y}=\mathbf{a}+\mathbf{b}_{1} \mathbf{X}_{1}+\mathbf{b}_{2} \mathbf{X}_{2}+\mathbf{b}_{3} \mathbf{X}_{3}+\mathbf{b}_{4} \mathbf{X}_{4}+$ $b_{5} X_{5}+e$

Keterangan:

Y : Kebangkrutan LPD

a : Konstanta

$\mathrm{X}_{1}$ : Proteksi Hukum

$\mathrm{X}_{2} \quad$ : Kompetensi Pengelola

$\mathrm{X}_{3}$ : Good Corporate Governance

$\mathrm{X}_{4} \quad$ : Peran Aktif warga

$\mathrm{X}_{5} \quad$ : Peran Badan pengawas internal Internal

e : Faktor kesalahan pengganggu (error)

Untuk menguji koefisien regresi secara parsial antara variabel bebas terhadap variabel terikat dengan tingkat signifikansi $5 \% \quad(a=0,05)$ digunakan uji $\mathrm{t}$ dangan rumusan hipotesis sebagai berikut:

$\mathrm{H}_{0}: \mathrm{b}_{0}=0$ artinya variabel bebas secara parsial tidak punya pengaruh siginifikan terhadap variabel terikat $\mathrm{H}_{1}: \mathrm{b}_{1} \neq 0$ artinya variabel bebas secara parsial mempunyai pengaruh 
yang signifikan terhadap variabel terikat

\section{HASIL DAN PEMBAHASAN}

\section{Deskriptif Responden}

Dalam penelitian ini dilakukan pengumpulan data dengan menyebarkan kuesioner sebanyak 63 kuesioner ke Lembaga Perkreditan Desa (LPD) se-Kabupaten Buleleng dengan 63 responden. Pengiriman kuesioner dilakukan pada Nopember 2018. Kuesioner tersebut kembali dalam kurun waktu 2 minggu sebanyak 63 responden
Rincian
responden
yang berpartisipasi dalam pengisian kuesioner adalah:
Berdasarkan Jenis Kelamin:
a) Laki-laki
$=48$ orang
b) Perempuan
$=15$ orang
Berdasarkan Jabatan:
a) Ketua
$=40$ orang
b) Bendesa
$=5$ orang
c) Pegawai
$=18$ orang

\section{Deskriptif Data}

Hasil Analisis Deskriptif Statistik

Hasil analisis deskriptif data dengan menggunakan bantuan program SPSS adalah sebagai berikut:

Tabel 1. Hasil Analisis Deskriptif Statistik

\begin{tabular}{lrrrrr}
\hline \multicolumn{7}{c}{ Descriptive Statistics } \\
\hline & $N$ & Minimum & Maximum & Mean & $\begin{array}{l}\text { Std. } \\
\text { Deviation }\end{array}$ \\
proteksi & 63 & 10,00 & 16,00 & 14,6508 & 1,34595 \\
kompetensi & 63 & 19,00 & 20,00 & 19,9365 & 0,24580 \\
gcg & 63 & 17,00 & 20,00 & 19,5238 & 0,80035 \\
paktifwarga & 63 & 18,00 & 24,00 & 22,1270 & 1,97151 \\
bdnpengawas & 63 & 20,00 & 28,00 & 26,6508 & 1,72420 \\
potensibangkrut & 63 & 8,00 & 16,00 & 10,3810 & 2,22470 \\
Sumber: Data Diolah, 2018 & & & &
\end{tabular}

Hasil pengukuran untuk variabel proteksi hukum (X1) dengan skor maksimum 16 sedangkan skor terendah yaitu 10. Untuk rata-rata (mean) proteksi hukum (X1) secara keseluruhan yaitu 14,65. Hal ini berarti keseluruhan variabel proteksi hukum memiliki kecenderungan pilihan jawaban responden memilih jawaban setuju. Variabel kompetensi pengelola (X2) dengan skor maksimum 20 sedangkan skor terendah yaitu 19. Untuk rata-rata (mean) kompetensi pengelola (X2) secara keseluruhan yaitu 19,94. Hal ini berarti keseluruhan variabel kompetensi pengelola memiliki kecenderungan pilihan jawaban 
responden memilih jawaban setuju. Untuk variabel GCG (X3) dengan skor maksimum 20 sedangkan skor terendah yaitu 17 . Untuk rata-rata (mean) GCG (X3) secara keseluruhan yaitu 19,52. Hal ini berarti Untuk rata-rata (mean) peran aktif warga (X4) secara keseluruhan yaitu 22,13. Hal ini berarti keseluruhan variabel proteksi hukum memiliki kecenderungan pilihan jawaban responden memilih jawaban setuju. Variabel peran badan pengawas internal (X5) dengan skor maksimum 28 sedangkan skor terendah yaitu 20. Untuk rata-rata (mean) peran badan pengawas internal (X5) secara keseluruhan yaitu 26,65. Hal ini berarti keseluruhan variabel proteksi hukum memiliki kecenderungan pilihan jawaban responden memilih jawaban setuju. Variabel potensi kebangkrutan (Y) dengan skor maksimum 16 sedangkan skor terendah yaitu 8 . Untuk rata-rata (mean) potensi kebangkrutan $(\mathrm{Y})$ secara keseluruhan yaitu 10,38. Hal ini berarti keseluruhan variabel proteksi hukum memiliki kecenderungan pilihan jawaban responden memilih jawaban tidak setuju. keseluruhan variabel GCG memiliki kecenderungan pilihan jawaban responden memilih jawaban setuju.

Variabel peran aktif warga (X4) dengan skor maksimum 24 sedangkan skor terendah yaitu 18 .

\section{Uji Kualitas Data (Uji Validitas dan Reliabilitas)}

Hasil pengujian validitas dan reliabilitas instrumen menunjukkan bahwa instrumen yang digunakan dalam penelitian ini adalah valid dan reliabel, yang ditunjukkan dengan nilai koefisien korelasi item-total variabel lebih besar dari 0,3 dan signifikansi lebih kecil dari 0,05. Hasil uji reliabilitas menunjukkan nilai cronbach alpha untuk semua variabel yang digunakan dalam penelitian ini lebih besar dari 0,70.

\section{Uji Asumsi Klasik}

\section{Uji Normalitas}

Berikut hasil pengujian normalitas menggunakan bantuan program SPSS. Berdasarkan tabel diatas, hasil pengujian normalitas dengan uji One Sample Kolmogorov Smirnov Test diatas menunjukkan hasil Asymp.Sig (2-tailed) sebesar 0,115 yang lebih tinggi dari 0,05 sehingga dikatakan data berdistribusi normal. 
Tabel 2. One Sample Kolmogorov Smirnov Test

\begin{tabular}{llr}
\hline & & $\begin{array}{c}\text { Unstandardized } \\
\text { Residual }\end{array}$ \\
\hline$N$ & 63 \\
Normal Parameters & Mean & 0,0000000 \\
& Std. Deviation & 1,14215121 \\
Most Extreme & Absolute & 0,196 \\
Differences & Positive & 0,196 \\
& Negative & $-0,111$ \\
Kolmogorov-Smirnov $Z$ & 1,559 \\
Asymp. Sig. (2-tailed) & 0,115 \\
a. Test distribution is Normal. & \\
\hline Sumber: Data Diolah, 2018
\end{tabular}

Uji Multikolinieritas

Uji multikolinieritas dilakukan untuk mengetahui apakah terjadi gejala korelasi antara variabel independen yang satu dengan variabel independen yang lain. Berikut merupakan hasil pengujian multikolinieritas:

Tabel 3. Hasil Pengujian Multikolinieritas

\begin{tabular}{llrr}
\hline & & \multicolumn{2}{c}{ Collinearity Statistics } \\
Model & & Tolerance & VIF \\
\hline 1 & (Constant) & & \\
& proteksi & 0,692 & 1,446 \\
& kompetensi & 0,957 & 1,045 \\
& Gcg & 0,778 & 1,286 \\
& paktifwarga & 0,728 & 1,373 \\
& bdnpengawas & 0,742 & 1,348 \\
\hline \multicolumn{2}{c}{ Sumber: Data Diolah, 2018 }
\end{tabular}

Hasil perhitungan nilai tolerance menunjukkan semua variabel bebas memiliki nilai tolerance lebih dari 0,10 . Hasil perhitungan nilai VIF juga menunjukkan semua variabel bebas memiliki nilai VIF < 10. Jadi dapat disimpulkan bahwa tidak ada gejala multikolinieritas antar variabel bebas.
Uji Heteroskedastisitas

Uji heteroskedastisitas diperoleh hasil pengujian sebagaimana disajikan pada Tabel 4. Berdasarkan tabel tersebut menunjukkan bahwa semua variabel nilai signifikansinya diatas $5 \%$ atau 0,05 sehingga dapat disimpulkan bahwa tidak terjadi heteroskedastisitas. 
Tabel 4. Hasil Uji Heteroskedastisitas

\begin{tabular}{|c|c|c|c|c|c|c|}
\hline \multirow{2}{*}{\multicolumn{2}{|c|}{ Model }} & \multicolumn{2}{|c|}{$\begin{array}{l}\text { Unstandardized } \\
\text { Coefficients }\end{array}$} & \multirow{2}{*}{$\begin{array}{c}\text { Standardized } \\
\text { Coefficients } \\
\text { Beta }\end{array}$} & \multirow[t]{2}{*}{$\mathrm{t}$} & \multirow[t]{2}{*}{ Sig. } \\
\hline & & $\mathrm{B}$ & Std. Error & & & \\
\hline \multirow[t]{6}{*}{1} & (Constant) & $-3,186$ & 12,434 & & $-0,256$ & 0,799 \\
\hline & proteksi & $-0,130$ & 0,135 & $-0,151$ & $-0,963$ & 0,339 \\
\hline & kompetensi & 0,332 & 0,629 & 0,071 & 0,528 & 0,600 \\
\hline & gcg & $-0,153$ & 0,214 & $-0,106$ & $-0,712$ & 0,479 \\
\hline & paktifwarga & 0,030 & 0,090 & 0,052 & 0,337 & 0,737 \\
\hline & bdnpengawas & 0,084 & 0,102 & 0,125 & 0,824 & 0,413 \\
\hline
\end{tabular}

a. Dependent Variable: abs

Sumber: Data Diolah, 2018

\section{Pengujian Hipotesis}

Uji Koefisien Determinasi $\left(R^{2}\right)$

Berdasarkan uji determinasi

(Tabel 5) diketahui bahwa nilai adjusted $\mathrm{R}$ square sebesar 0,233 menunjukkan bahwa variasi variabel independen dapat menjelaskan variabel dependennya sebesar 23,3\%, sedangkan sisanya sebesar $76,7 \%$ dijelaskan oleh variabel/faktor lain yang tidak dianalisis dalam model regresi.

Tabel 5. Hasil Uji Determinasi

\begin{tabular}{llrcc}
\hline \multicolumn{5}{c}{ Model Summary } \\
\hline Model & $R$ & $R$ Square & Square & Std. Error of the \\
1 & $.543^{\mathrm{a}}$ & .295 & .233 & 1.94791 \\
\hline
\end{tabular}

a. Predictors: (Constant), bdnpengawas, kompetensi, paktifwarga, gcg, proteksi Sumber: Data Diolah, 2018

\section{Uji Signifikansi Regresi}

Uji signifikansi

regresi menunjukkan apakah terdapat pengaruh variabel independen terhadap variabel dependen secara parsial. Dari perhitungan SPSS diperoleh nilai signifikansi sebagaimana disajikan pada Tabel 6 . Hasil analisis regresi berganda dihasilkan model regresi sebagai berikut:
$Y=75,633-0,0238 X 1-2,3 X 2-$ $0,184 \times 3-0,052 \times 4-0,419 \times 5+e$

Berdasarkan hasil uji signifikansi diketahui bahwa:

a) Proteksi Hukum dengan nilai signifikansi sebesar $0,286>$ 0,05 artinya hipotesis pertama ditolak bahwa tidak terdapat pengaruh proteksi hukum terhadap potensi kebangkrutan LPD 
b) Kompetensi Pengelola dengan nilai signifikansi sebesar 0,029 $<0,05$ artinya hipotesis kedua diterima bahwa terdapat pengaruh kompetensi pengelola terhadap potensi kebangkrutan LPD.

c) GCG dengan nilai signifikansi sebesar 0,602>0,05 artinya hipotesis ketiga ditolak bahwa tidak terdapat pengaruh GCG terhadap potensi kebangkrutan LPD.

d) Peran Aktif Warga dengan nilai signifikansi sebesar $0,724>$ 0,05 artinya hipotesis keempat ditolak bahwa tidak terdapat pengaruh peran aktif warga terhadap potensi kebangkrutan LPD.

e) Peran Badan pengawas internal dengan nilai signifikansi sebesar $0,015<0,05$ artinya hipotesis kelima diterima bahwa terdapat pengaruh peran badan pengawas internal terhadap potensi kebangkrutan LPD.

Uji F

Berdasarkan tabel 7 tampak bahwa uji $F$ berdasarkan nilai signifikansinya yaitu $0,001<0,05$ artinya bahwa secara bersama-sama (simultan) terdapat pengaruh variabel $\mathrm{X} 1, \mathrm{X} 2, \mathrm{X} 3, \mathrm{X} 4$ dan X5 terhadap Y.

Tabel 6. Hasil Uji Signifikansi

Coefficients ${ }^{a}$

\begin{tabular}{llrrrrr}
\hline \multirow{2}{*}{ Model } & \multicolumn{2}{c}{ Unstandardized } \\
Coefficients & \multicolumn{2}{c}{$\begin{array}{c}\text { Standardized } \\
\text { Coefficients }\end{array}$} \\
& & B & Std. Error & Beta & t & \multicolumn{1}{c}{ Sig. } \\
\hline 1 & (Constant) & 75,633 & 20,333 & & 3,720 & 0,000 \\
& proteksi & $-0,238$ & 0,221 & $-0,144$ & $-1,078$ & 0,286 \\
& kompetensi & $-2,300$ & 1,029 & $-0,254$ & $-2,236$ & 0,029 \\
& gcg & $-0,184$ & 0,351 & $-0,066$ & $-0,525$ & 0,602 \\
& paktifwarga & $-0,052$ & 0,147 & $-0,046$ & $-0,355$ & 0,724 \\
& bdnpengawas & $-0,419$ & 0,167 & $-0,324$ & $-2,514$ & 0,015 \\
\hline
\end{tabular}

a. Dependent Variable: potensibangkrut

\section{Pembahasan}

Pengaruh Proteksi Hukum terhadap Potensi Kebangkrutan LPD

Berdasarkan hasil penelitian yang didapatkan, hipotesis pertama ditolak yang menyatakan bahwa proteksi hukum tidak berpengaruh terhadap potensi kebangkrutan LPD. Sebagai lembaga keuangan milik adat, Lembaga Perkreditan Desa (LPD) seharusnya dapat menjamin dana 
Tabel Hasil Uji F

\begin{tabular}{|c|c|c|c|c|c|c|}
\hline \multicolumn{7}{|c|}{$A N O V A^{b}$} \\
\hline Model & & $\begin{array}{c}\text { Sum of } \\
\text { Squares }\end{array}$ & $d f$ & $\begin{array}{c}\text { Mean } \\
\text { Square }\end{array}$ & $F$ & Sig. \\
\hline \multirow[t]{3}{*}{1} & Regression & 90,579 & 5 & 18,116 & 4,774 & $0,001^{a}$ \\
\hline & Residual & 216,278 & 57 & 3,794 & & \\
\hline & Total & 306,857 & 62 & & & \\
\hline
\end{tabular}

a. Predictors: (Constant), bdnpengawas, kompetensi, paktifwarga, gcg, proteksi

b. Dependent Variable: potensibangkrut

Sumber: Data Diolah, 2018

nasabahnya. Pada dasarnya sangat diperlukan aturan yang jelas untuk memproteksi dana masyarakat yang dihimpun agar keberadaan lembaga yang tidak termasuk LKM ini dapat tetap bertahan di masyarakat.

Hasil penelitian menyatakan bahwa tidak ada pengaruh proteksi hukum terhadap potensi kebangkrutan LPD dapat dianalisis bahwa yang menyebabkan potensi kebangkrutan LPD tidak berkaitan dengan adanya proteksi hukum dalam hal ini yaitu awig-awig yang selama ini masih menjadi satusatunya landasan hukum LPD di Bali. Hal ini juga disebabkan karena pada dasarnya pengelolaan LPD harus dilakukan secara professional tidak cukup menggunakan awig-awig yang sifatnya hanya mengatur kehidupan bermasyarakat berdasarkan asas kekeluargaan dan menyama braya yang berlaku sentral di desa pakraman tersebut saja.
Jati diri LPD memang berakar dari masyarakat adat sehingga pengaturannya harus berdasarkan awig-awig, oleh karena itu jika bisa dikelola secara professional harusnya mengakomodir ketentuan-ketentuan yang ditentukan dalam peraturanperaturan yang mengatur tentang lembaga keuangan non-bank.

Pengaruh Kompetensi Pengelola terhadap Potensi Kebangkrutan LPD

Berdasarkan hasil penelitian bahwa hipotesis kedua diterima yang menyatakan kompetensi pengelola berpengaruh terhadap potensi kebangkrutan LPD.Hal ini sekaligus menyatakan bahwa mendukung adanya peningkatan kompetensi pengelola yang berkaitan dengan tingkat pengetahuan dan ketrampilan pengelola/pengurus LPD.

$$
\text { Kompetensi pengelola }
$$
merupakan bagian dari fungsi manajemen yang perlu dikembangkan demi terselenggaranya efektivitas 
pengelolaan LPD, maka dalam upaya meningkatkan efektivitas serta efisiensi dari sebuah LPD, diperlukan seperangkat perilaku para pengelola yang meliputi kemampuan umum, ketrampilan, dan pengetahuan mengenai kebijaksanaan, aturan dan pedoman pelaksanaan tugas pengelola bagi tercapainya tujuan organisasi sesuai dengan posisi atau jabatan yang disandangnya.Dengan adanya kreatifitas dan pemikiran inovatif dari para pengelola akan banyak memberikan gagasan dan pemikiran baru yang konstruktif dan produktif.

Sehingga dapat disimpulkan bahwa, jika pengelola bukan merupakan orang yang handal dan mampu membuat gagasan yang hebat, maka bisa dilihat dari segi sistem pengendalian internal dan output yang dihasilkan kurang bisa dipertanggungjawabkan. Maka dari itu, setidaknya para pengelola ini harus memiliki cukup pengetahuan dan pemahaman tentang proses kreatif sehingga tidak membendung atau menghambat jenis pikiran yang segar dan berada dalam LPD.

Pengaruh GCG terhadap Potensi Kebangkrutan LPD

Berdasarkan hasil penelitian yang menyatakan bahwa hipotesis ketiga ditolak karena merujuk dari pernyataan bahwa LPD kedepannya harus menyusun kerangka hukum yang ideal dengan merumuskan tata kelola (GCG). Penelitian dari Saputra dan Darmawan (2014) menyatakan bahwa implementasi prinsip-prinsip GCG memiliki pengaruh terhadap kinerja LPD. LPD dikelola secara terpisah dengan krama desa sehingga memungkinkan terjadinya konflik keagenan.

Selain itu LPD menggunakan pinjaman dari Bank Pembangunan Daerah (BPD Bali). Hal itulah yang menjadi faktor utama prinsip-prinsip good corporate governance dirasa wajib diterapkan oleh LPD untuk mengurangi konflik kepentingan antara pengelola LPD sebagai agen dengan pemilik yaitu krama desa (warga masyarakat) dan antara pengelola LPD dengan kreditur yaitu Bank Pembangunan Daerah Bali serta dapat menjaga hubungan baik dan menjamin terpenuhinya hak dari pihak-pihak yang berkepentingan dengan fungsi dan tujuan LPD itu sendiri.

Akan tetapi, LPD di Kabupaten Buleleng yang dijadikan sampel penelitian yang memang pengelolaannya masih mengikuti aturan desa adat belum siap untuk mengikuti pengelolaan organisasi/perusahaan yang bersifat bussines orientationdan sudah 
mengarah kepada manajemen yang professional.

Pengaruh Peran Aktif Warga terhadap Potensi Kebangkrutan

Berdasarkan hasil penelitian bahwa hopotesis keempat ditolak yang menyatakan peran aktif warga tidak berpengaruh terhadap potensi kebangkrutan LPD.Hasil penelitian ini menunjukkan bahwa LPD yang nyatanya menjadi milik desa pakraman ternyata tidak bergantung sepenuhnya pada peran aktif warga desa adat.Sesuai dengan pernyataan bahwa masalah utama LPD saat ini adalah bagaimana meningkatkan kompetensi dari para pengelola mulai dari pengelolaan hingga pengawasan. Jika semua komponen ini berfungsi dengan baik maka LPD akan bisa berkembang dengan baik juga. Akan tetapi, yang lebih penting dari semuanya itu adalah bagaimana peran aktif warga dalam pengembangan LPD.Masyarakat harus aktif menanyakan perkembangan LPD (Bali Post, 1 Oktober 2013). Walaupun penelitian ini berusaha mendukung pernyataan tersebut, akan tetapi hasil penelitian menyatakan berbeda. $\mathrm{Hal}$ ini disebabkan karena kenyataannya warga jarang atau bahkan tidak dilibatkan pada saat pengambilan keputusan mengenai LPD.Dari jawaban pertanyaan kuesioner juga sebagian responden menjawab warga masyarakat jarang dilibatkan dalam penentuan kebijakan terkait LPD.

\section{Pengaruh Peran Badan Pengawas Internal terhadap Potensi Kebangkrutan LPD}

Berdasarkan hasil penelitian menyatakan bahwa hipotesis kelima diterima, hal ini berarti peran badan pengawas internal berpengaruh terhadap potensi kebangkrutan LPD.Hal ini berarti peran badan pengawas internal harus lebih ditingkatkan lagi dan dikembalikan ketujuan awal pembentukannya sebagai badan pengawas internal yang bersifat independen yang dipilih oleh masyarakat dengan kemampuan yang dimiliki seperti kemampuan dalam bidang pengawasan dan pemeriksaan serta mampu memberikan rekomendasi berdasarkan hasil pemeriksaan yang dilakukan.

Hasil penelitian ini mendukung penelitian yang dilakukan oleh Wedayani dan Jati (2013) yang menyatakan bahwa tingkat efektivitas peran badan pengawas internal internal dalam LPD dioptimalkann maka fungsi badan pengawas internal internal akan semakin efektif dan mampu meningkatkan kinerja LPD itu sendiri. 
Peran badan pengawas internal internal merupakan variable yang dominan berpengaruh terhadap potensi permasalahan LPD sehingga sampai mengalami kebangkrutan. Hal ini artinya bahwa peran badan pengawas internal internal perlu dioptimalkan kembali supaya system pengawasan di LPD semakin di perketat, walaupun peran badan pengawas internal intern dalam mengawasi operasional LPD bisa dilakukan oleh siapa saja di desapakraman bersangkutan tanpa mengenal jenjang dan jenis pendidikan. Semakin besar asset LPD maka ruang lingkup pengawasan menjadi semakin luas dan kompleks, dengansendirinya memerlukan pengetahuan dan kompetensi yang semakin khusus.

Mengingat pentingnya peranan badan pengawas internal, maka ia harus memiiki kejelasan dalam struktur organisasi yang ada, keahlian teknis, dan pola pikir yang membuat mampumenjalankan tata kelola, bimbingan, dan tanggung jawab.

\section{KESIMPULAN, IMPLIKASI DAN KETERBATASAN PENELITIAN}

\section{Kesimpulan}

Berdasarkan hasil penelitian yang telah dijelaskan diatas, maka dapat disimpulkan sebagai berikut:
1. Proteksi hukum secara kelembagaan dan berlebihan tidak memiliki pengaruh signifikan terhadap potensi kebangkrutan LPD. Hal ini berarti proteksi hukum yang ada sampai saat ini sudah cukup hanya menggunakan awig-awig. Dalam hal ini dapat disimpulkan bahwa proteksi hukum secara umum belum diperlukan karena LPD berbasis hukum adat sudah sangat efektif dan masih dianggap mampu untuk mengikat para nasabah dan meminimalisir kredit macet dan segala kecurangan lainnya, baik yang dilakukan oleh pengelola LPD ataupun pihak eksternal.

2. Kompetensi pengelola memiliki pengaruh terhadap potensi kebangkrutan LPD. Hal ini berarti bahwa di LPD sangat perlu SDM yang memiliki ketrampilan dan kemampuan yang kompeten dibidang pengelolaan keuangan dan manajerial.

3. Good Corporate Governance tidak memiliki pengaruh terhadap potensi kebangkrutan LPD. Hal ini berarti bahwa LPD memang belum siap untuk menerapkan prinsip-prinsip GCG karena masih terikat dengan aturan desa adat, walaupun banyak pernyataan yang mendukung 
bahwa GCG penting diterapkan di LPD. Ketidaksiapan LPD dalam penerapan GCG disebabkan dalam konsep pengelolaan LPD tidak bisa terlalu mengekang dan mengandung sistem yang detail, sehingga pengelolaan LPD hanya perlu diperkuat dengan metode pengawasan yang berjenjang dan melibatkan masyarakat adat dan berbasis kesepakatan bersama serta keyakinan yang relevan di setiap masyarakat dimana tempat LPD tersebut berdiri.

4. Peran aktif warga tidak memiliki pengaruh terhadap potensi kebangkrutan LPD. Hal ini berarti bahwa warga yang seharusnya memiliki peran penting dalam pengawasan LPD tidak melakukan hal itu, bahkan kecendrungan masalah yang dialami oleh LPD bersumber dari masyarakat itu sendiri, sehingga keterlibatan warga masyarakat dalam pengambilan keputusan tentang LPD tidak efektif. Serta lebih cenderung menguatkan keyakinan dan modal sosial yang dimiliki. Modal sosial yang dimiliki oleh masyarakat adalah berupa kepercayaan dan ketaatan yang kuat terhadap para pemimpinnya. Terutama pada desa adat, modal sosial yang ada bisa memberikan standar moral yang tinggi terhadap para pengelola LPD. Kepercayaan yang kuat terhadap pengelola LPD, diyakini karena ada kehendak Tuhan yang menginginkan orang tersebut duduk dalam struktur organisasi LPD. Sehingga masyarakat desa memberikan kepercayaan dan kepatuhan yang besar bagi para pemimpin dan pengelola LPD untuk melakukan pengelolaan keuangan. Dengan adanya kepercayaan terhadap hal-hal niskala, para pengelola LPD juga akhirnya memiliki standar moral yang tinggi. Sebab selain sebagai pengelola LPD juga merupakan bagian dari krama desa yang percaya akan nilai-nilai budaya, tradisi, dan juga nilai ketuhanan. Sehingga melalui modal sosial ini, para pengelola LPD akan memiliki komitmen yang kuat untuk melakukan pengelolaan keuangan yang bersih dan benar, karena ada kepercayaan sosial yang harus mereka jaga.

5. Peran badan pengawas internal berpengaruh terhadap potensi kebangkrutan LPD. Hal ini berarti bahwa peran badan pengawas internalperlu dioptimalkan dengan rekruitmen yang transparan berdasarkan kemampuan pengawasan dan 
pemeriksaan yang dimiliki, oleh sebab itu, badan pengawas internaldiposisikan sebagai internal auditor LPD.

\section{Saran}

Berdasarkan hasil penelitian yang telah dilakukan maka diajukan saran sebagai berikut:

1. Berdasarkan hasil penelitian supaya lebih memperhatikan faktor-faktor yang berpengaruh ataupun yang tidak berpengaruh untuk menuju kepada pengelolaan LPD yang lebih efektif.

2. Variabel yang mempengaruhi potensi kebangkrutan LPD supaya diperluas lagi dengan mempertimbangkan factor lainnya seperti: implementasi tri hita karana, penyajian laporan keuangan LPD, gaya kepemimpinan dan variabelvariabel yang berkaitan dengan organisasi dan sumber daya manusia.

3. Pemerintah agar lebih focus dalam pengawasan dan pembinaan LPD mengingat LPD merupakan jati diri masyarakat di Bali.

\section{REFERENSI}

Atmadja, A.T., N.A.S Darmawan dan K.A.K Saputra. 2015. Pengaruh
Implementasi Good Corporate Governance dan Proteksi AwigAwig Terhadap Kinerja Lembaga Perkreditan Desa (LPD) Dengan Budaya Menyama Braya Sebagai Variabel Moderasi (Studi Pada LPD Se-Kabupaten Buleleng)

Atmadja, A.T. and K.A.K. Saputra. 2015. The Effect of Total Quality Management, Emotional Intelligence, Critical Sociology, Creativity and Mentality of Education Accounting. International Research Journal of Finance and Economics. Issue 139. Page. 47-61.

Atmadja, A.T and K.A.K. Saputra. 2015. Analysis of Some Factors Affecting the Needs of External Audit Institusion of Rural Village (Studies on Rural Credits Institutions Throughout Buleleng). European Journal of Social Sciences 51 (1), 116-132

Atmadja, A.T., I.M.P. Adiputra and KAK Saputra. 2015. The Determination of Some Factors that Affecting Bankruptcy of Village Credit Institutions (LPD) In Buleleng District. European Journal of Economics, Finance and Administrative Sciences 72. 5-19.

Bali Post, 2010. "173 LPD Bangkrut". Bali Post, 13 Nopember 2010. Halaman: 16

Covarrubias, M. 1972. Island of Bali. Oxford University Press.

$\begin{array}{ccr}\text { Hartadi, B. } & 1999 . & \text { Sistem } \\ \text { Pengendalian } & \text { Intern } & \begin{array}{r}\text { dalam } \\ \text { dengan }\end{array} \\ \text { Hubungannya } & & \text { Audit. } \\ \text { Manajemen } & \text { dan } & \text { Audakarta: BPFE. }\end{array}$

Peraturan Daerah Provinsi Bali Nomor 8 Tahun 2002 Tentang Lembaga Perkreditan Desa (LPD). 
Peraturan Daerah Provinsi Bali Nomor 4 Tahun 2012 Tentang perubahan Kedua Atas Peraturan Daerah Provinsi Bali Nomor 8 Tahun 2002 Tentang Lembaga Perkreditan Desa

Pitana, I G. 1994. "Desa Adat dalam Arus Modernisasi”. Dalam I Gede Pitana, ed. Dinamika Masyarakat dan Kebudayaan Bali. Denpasar: Penerbit BP.

Saputra, K.A.K. 2015. Prinsip Pang Pada Payu Sebagai Dimensi Good Governance Dalam Sengketa Kredit Macet (Studi Fenomenologi pada LPD Desa Kerobokan, Kabupaten BulelengBali). Jurnal Ilmiah Akuntansi dan Humanika 5 (1), 1-23

Saputra, K.A.K., dan P.S. Kurniawan. 2017. Konsep Good Corporate Governance Dan Fungsi Badan Pengawas Sebagai Internal Auditor LPD Di Bali. Simposium Nasional Akuntansi XX, Universitas Jember 2017

Saputra, K.A.K dan G.M. Tama. 2018. Pengaruh Kompetensi, Koordinasi Dan Kompleksitas Tugas Terhadap Kinerja Badan Pengawas Sebagai Internal Auditor Di Lembaga Perkreditan Desa (LPD). Prosiding Konferensi Regional Akuntansi V.

Setyawan, Komang Meitradi dan I Gusti Ayu Made Asri Dwija Putri. 2013. Pengaruh Good Corporate Governance Terhadap Kinerja Keuangan Lembaga Pekreditan Desa Di Kecamatan Mengwi Kabupaten Badung. E-Jurnal
Akuntansi Universitas Udayana. 2013, 586-598.

Sulistyowati, A. "Keuangan Pedesaan Dari dan untuk Masyarakat Adat”. Kompas, 28 Januari 2011. Halaman: 35.

Surat Keputusan (SK) Gubernur No. 972 Tahun 1984 tentang Pendirian Lembaga Perkreditan Desa di Provinsi Daerah Tingkat I Bali

Undang-undang Republik Indonesia Nomor 1 Tahun 2013 Tentang Lembaga Keuangan Mikro.

Uyanto, Stanislaus S. (2009). Pedoman Analisis Data dengan SPSS. Graha Ilmu, Yogyakarta.

Warren, C. 2010. "Adat dalam Praktik dan Wacana Orang Bali: Memosisikan Prinsip Kewargaan dan Kesejahteraan Bersama”. Dalam James S. Davidson, dkk. (Ed.). Adat dalam Politik Indonesia. Jakarta: Yayasan Pustaka Obor Indonesia. Halaman: 187-219.

Wedayani, Ni Wayan dan I Ketut Jati. 2013. Efektivitas Fungsi Badan pengawas internal Sebagai Internal Auditor Dalam Pengawasan Terhadap Pemberian Kredit Pada LPD Di Kecamatan Rendang, Selat, Sidemen, Dan Manggis Kabupaten Karangasem, Provinsi Bali. Jurnal Ilmiah Akuntansi dan Humanika, Universitas Pendidikan Ganesha 